\title{
A PROSA TRANSGRESSORA DE THERESA MARGARIDA DA SILVA E ORTA
}

\author{
Beatriz Amazonas Cardoso ${ }^{1}$
}

\begin{abstract}
Resumo: O fato de Theresa Margarida da Silva e Orta, autora de As Aventuras de Diófanes, não pertencer aos cânones da literatura portuguesa nem da feminina constitui uma problemática que instigou nossa leitura. Criadora de um protorromance inspirado em obras clássicas como Odisseia (de Homero) e Télémaque (de Fénelon), Theresa Margarida fotografa, femininamente, os cenários políticos, religiosos, sociais e culturais da época, em um ambiente dominantemente masculino. Como das mulheres letradas só era esperada e permitida a produção poética, a postura da autora portuguesa tem a conotação de transgressora, à luz dos conceitos de Foucault.
\end{abstract}

Palavras-Chave: Transgressão; Literatura feminina; Cânones portugueses.

\section{A TRANSGRESSOR NAMED THERESA MARGARIDA DA SILVA E ORTA}

Abstract: The fact that Theresa Margarida was not part of the canons of neither Portuguese nor feminine literature is the main point of our text. Inspired by Homer's Odyssey and Fénelon's Télémaque, Theresa Margarida, who created the "protorromance" As Aventuras de Diófanes, is faced by this work as a female portraitist of the political, religious, social, and cultural scenarios of her time, within a dominantly male environment. The Portuguese writer can be considered a transgressor of that time, through the thoughts of Foucault.

Keywords: Transgression; Women's literature; Portuguese canon.

Em 1752, surge em Portugal uma obra literária escrita por uma mulher portuguesa, Theresa Margarida da Silva e Orta, nascida no Brasil, sendo a primeira obra em prosa de autoria feminina, em Língua Portuguesa: As Aventuras de Diófanes.

Dividida em seis livros, a obra (aqui referenciada como AD) narra uma viagem feita pelos Reis de Tebas para a Ilha de Delos. Forte tempestade afasta a esquadra protetora e, desprotegidos, são aprisionados e a família desmembrada. A princesa Hemirena será o elemento escolhido para a re-união da família, e para isso se apresentará travestida de homem.

\footnotetext{
${ }^{1}$ Doutora em Letras pela FFLCH/ USP - Literatura Portuguesa. Atual Professora de Letras do Centro Universitário Estácio Radial de São Paulo.
} 
No Prólogo, Theresa Margarida da Silva e Orta anuncia: "Eu sou Mulher e não tenho a pena de Homero..." - mesmo assim tem a ousadia de escrever em prosa uma aventura nos moldes da Odisseia.

O fato de Theresa Margarida da Silva e Orta não pertencer aos cânones da literatura portuguesa nem da feminina constitui uma problemática instigante a ser discutida, motivo deste artigo.

Fadada à vida privada, até finais do século XVIII e início do século XIX, a mulher escritora ficava circunscrita, em sua topologia e temática, ao âmbito familiar que lhe era permitido, sendo sua escritura também confinada ao lar, ao castelo, aos segredos de alcova, às intimidades e ao sentimentalismo.

Tendo um sonho antigo - falar e ser ouvida -, essa mulher criadora traz consigo atrelado outro sonho, mais moderno: ser respeitada pelo que disse.

Em toda a Europa, no período entre os séculos XVI e XVII, tanto a prática da leitura como a da escritura estabelecem modelos de comportamento quer social, quer individual, determinando as condutas culturais de cada época. Se ler era privilégio de poucos, escrever só era permitido aos homens.

Se as limitações de escrita e leitura tinham por princípio um público restritamente masculino, que se dizer do universo feminino? A demarcação do espaço da literatura feminina, no correr da história literária europeia do século XVIII, exige um olhar para as grandes linhas a que tinham acesso as mulheres-autoras da época.

Limitadas (ou diríamos acuadas?) ao espaço da Poesia e da Epístola, ainda assim é interessante a produção feminina conhecida a partir do século XVI, principalmente no eixo Londres-Paris.

Distanciada dos cânones masculinos reconhecidos, em todas as épocas, essa literatura de autoria feminina teve de percorrer um espaço bipolarizado pela oposição feminino x masculino, polaridade esta oriunda da formação judaico-cristã que se estende do Oriente ao Ocidente. Para muitos críticos, há um estilo de escrita feminino e um masculino, independentemente de serem criados por homens ou por mulheres. Frases longas, encadeadas em subordinação e amplamente ramificadas, onde abundam os oximoros, os paradoxos, as contradições, os fragmentos, os variados pontos de vista, todos são recursos culturalmente femininos (DAL FARRA, 2002).

No entanto, em termos literários, percebe-se que essa estrutura pode ser quebrada pelo estilo próprio de cada autor. Werther (Goethe) é um personagem saído de uma pena 
masculina que transgride todas as características ditas falocêntricas, posto que sua expressão deixa entrever uma alma sensível e delicada, facilmente atingida pelo desencanto amoroso, por meio de uma retórica lacrimosa.

Quebrar expectativas talvez seja a tônica precípua para explicar pontos de vista, estilos, representatividade e temáticas exploradas pelas mulheres-escritoras da época estudada. Conforme Barthes (apud KADOTA, 1999), as informações codificadas que transmitem a mensagem passam por um processo de análise que marcam as "zonas de leitura". Assim, os códigos, as citações, os sentidos dados ao texto estão submetidos a uma norma operatória que insiste em que a análise semiótica parte da mensagem para o código (REIS, 1981. P.337-342).

Se Roland Barthes afirma que o escritor tem a responsabilidade de "um trabalho político", isto é, de operar uma mutação na linguagem, de "revirá-la", de "deportá-la da gramática para o discurso", essa responsabilidade está isenta do fato de gêneros diferentes estabelecerem sua manifestação (KADOTA, 1999. P.65). Se Barthes o afirma, Theresa Margarida não o deixa mentir. Destinada à vida doméstica, nem sempre a mulher acolherá, acatará, aceitará essa sua vivência imposta, contra a qual, muitas vezes, não terá vez nem vOZ.

Nascida em um Brasil colonial, levada ainda pequena para um Portugal regido por um imperialismo ao mesmo tempo cego e ambicioso, Theresa Margarida cresceu em um ambiente onde se combinaram diversos incidentes históricos. Interna do Convento das Trinas, Theresa Margarida aprendeu a se expressar, tendo desenvolvido seu espírito crítico e seletivo. Sua escolha de vida, com apenas 16 anos, mostra que não aceita a invisibilidade da mulher (como era imposto pela sociedade em que vivia), a quem apenas eram atribuídos (cinicamente) três defeitos: "a ignorância, a inconstância e a formosura", conforme defendido em carta de Gertrudes Margarida de Jesus².

Em tal cenário de aprendizagem, Theresa Margarida convive com um pai autoritário, a quem contraria, casando-se à revelia, com apenas 17 anos, apoiada por seu confessor e pela Lei.de 13 de novembro de 1651, de D. João IV.

Pouco ou quase nada se sabe desse período entre o casamento e a primeira publicação do protorromance em questão, em 1752.

${ }^{2}$ Cf. apresentado em Espelho crítico no qual claramente se vem alguns defeitos das mulheres, de Frei Amador do Desengano - fabricado na loja da verdade pelo irmão[...], Lisboa, Antônio Vicente da Silva, 1761. Escrito conforme texto original, de 1761. 


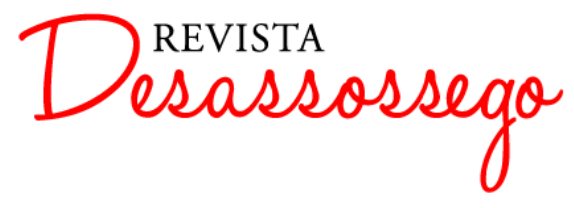

DESASSOSSEGO 17 | JUN/2017 | ISSN 2175-3180

DOI: http://dx.doi.org/10.11606/issn.2175-3180.v9i17p85-101

Theresa Margarida ousa sair da sombra em que a História a colocara e usa um instrumento de movimentação para registrar essa ousadia, um recurso de exploração ou de navegação, onde a liberdade de expressão é permitida: escrever um livro, quebrando assim as expectativas sociais. Essas quebras ou transgressões poderiam se manifestar das mais diversas maneiras, quer na vida diária - pela omissão das tarefas, pelo abandono aos filhos, pelo autodesprezo físico e/ou emocional -, quer nas atividades proibidas como as intelectuais, políticas, públicas. Ela o faz com a transgressão pelo uso da palavra.

Segundo Foucault, a transgressão é uma fina linha que separa o permitido do apenas sonhado. Determina limites, mas não é um espaço limitado, é apenas o início de um caminho que continuamente se recomeça. No entender do filósofo, essa transgressão não ocupa polo oposto ao limite, mas sim está ligada a esse limite em uma relação espiralada. É preciso, diz ele,

...para tentar pensá-la, pensar a partir dela e no espaço que ela abarca, é necessário desafogá-la das suas afinidades suspeitas com a ética. Libertá-la do que é o escandaloso ou o subversivo, ou seja, daquilo que é animado pela potência do negativo (FOUCAULT, 1963, p.33).

No entender de Foucault, a transgressão não é o oposto de nada, nem direciona para a violência ou para a destruição do já sacramentado. Ao contrário, ela faz brilhar a audácia da criação do inusitado.

Sob esse enfoque, tanto a poesia quanto a prosa femininas, que ousamos chamar de "transgressoras", são meritórias e dignas da atenção aqui dedicada, posto que elas constituem "a afirmação da divisão": elas são o protótipo da contestação, considerado aqui como "o gesto que reconduz aos seus limites".

A contestação não é o esforço do pensamento para negar existências ou valores, é o gesto que reconduz cada um deles aos seus limites, e por aí ao Limite no qual se cumpre a decisão ontológica: contestar é ir até o núcleo vazio no qual o ser atinge seu limite e no qual o limite define o ser. (FOUCAULT, 1963, p.34).

Culta e preparada para viver em um mundo que, embora masculino pelo poder, já apresentava figuras femininas que se salientavam nas artes, nos meios sócio-políticos e sociais, Theresa Margarida vê, na prática das Letras, a porta de saída para expor seus pensamentos. Seria aceita nesse mesmo mundo que castrava a produção feminina por ideologia? Seria aceita em um Portugal que passava pelo Santo Ofício, numa caça às bruxas, 


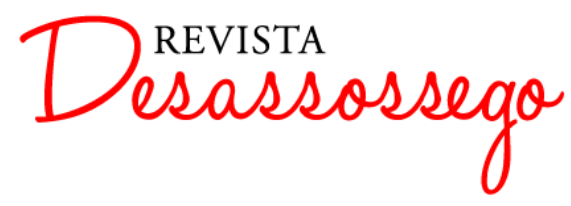

DESASSOSSEGO 17 | JUN/2017 | ISSN 2175-3180

DOI: http://dx.doi.org/10.11606/issn.2175-3180.v9i17p85-101

vendo na figura da mulher a encarnação do diabo? À mulher não era dado o direito de pensar e, muito menos, de externar seu pensamento. Quantas já haviam ousado e poderiam ser consideradas vencedoras? Trocar de nome, de identidade, usar pseudônimos tudo pareceria falso, para não dizer mutilante.

Paralelamente às poetisas Soror Maria do Céu, Soror Violante do Céu, Bernarda Ferreira de Lacerda, Catarina Micaela Lencastre, Soror Madalena da Glória e a Marquesa de Alorna, Theresa Margarida opta pelo caminho das lágrimas, como catarse de emoções reprimidas e expressas em uma prosa de inspiração masculina (Homero). Criando um texto onde subjaz um discurso de marcas singulares, linguisticamente falando, a autora faz escolha de um gênero ainda incipiente nos meios literários, em uma posição translinguística à luz de Julia Kristeva (1984), que relaciona o uso da língua com a fala comunicativa, transformando-a em um produto, tornando possível se identificar Aventuras de Diófanes com o gênero romanesco. Considerando-se que o aparecimento "oficial" do romance se dá no século XIX, com o advento da sociedade burguesa europeia, torna-se inquietante o aparecimento deste gênero na literatura portuguesa, até então direcionada pela mão autoritária do Estado e pelo olhar castrador da Igreja.

Para desvendar os mistérios ocultos dessa escrita, aparentemente ingênua, a análise do discurso revelador pode ser feita pelo estudo dos cruzamentos ou embricamentos das séries textuais, dos enunciados, das estratégias, dos monólogos, dos conteúdos ideológicos que produzem efeitos de sentido e que assim o definem, permitindo a passagem de objeto para sujeito (PÊCHEUX, 1997 P.123).

No espaço explorado por Theresa Margarida - o protorromance - é oferecida a análise de um duplo discurso: o discurso literário da autora luso-brasileira e o discurso de uma psicologia sócio-histórica do momento dessa produção. Além das possíveis leituras admitidas, também a escritora portuguesa faz uma análise do ambiente em que apresenta sua obra, em sua própria defesa, como se para isso precisasse adotar uma posição de autoproteção contra uma sociedade punitiva e cruel: "Acham-se as gentes tão dominadas de paixões particulares, que muitas vezes só se estimam as obras para maltratarem os seus Autores; ...” (AD, p.03)

Theresa Margarida apresenta um texto não tão rico em metáforas e alegorias como seria necessário em momentos de resistência política -, mas pleno de significados. A autora trabalha nos limites do dizer, quer no tema escolhido, quer nos monólogos de seus 
personagens femininos, quer na postura pseudopedagógica de seu dizer intencional de "ensinar boas maneiras às moças".

A supressão do discurso poético que seguia as normas da época se justifica, em Theresa Margarida, pelo privilégio de um discurso engajado, prosaico, não porque aquele não mereceria respeito e aceitação, mas por uma postura discursiva de transgressão.

$\mathrm{Na}$ temática escolhida por Theresa Margarida, a imagem do viajante tebano pelas ilhas gregas é "falsa" em relação à realidade grega. Porém, o desvio do olhar da autora, da sociedade portuguesa para outra sociedade ideal, faz parte de um universo mítico que valoriza pessoas, lugares, ideias.

Sendo o escritor um solitário que busca na verdade ampla a sua verdade individual, Theresa Margarida delimita as diferentes solidões e sua atuação na vida cotidiana, tomando medidas de progressão desse individualismo, analisando os diversos grupos que a cercam, da família ao Estado, formando uma consciência individual. Esse caminhar solitário não a exclui, como escritora, das comunidades a que pertence. Pelo contrário, é nelas que encontra os traços fundamentais que caracterizam e marcam a mentalidade de seu espaço e de seu tempo.

Escritora portuguesa do Século das Luzes, Theresa Margarida apresenta alguns traços distintivos de seu momento que, à luz de Mandrou, podem-se relacionar como (MANDROU,1979):

1) Hipersensibilidade de temperamentos, como medos, mobilidade sentimental: "São tão infelizes as mulheres, que bastando que os homens sejam bons, a elas não basta que o sejam, porque é preciso que também o pareçam.” (AD, p.97);

2) Antagonismos ou preferências sociais, marcando os grupos em função dos afetos e hostilidades vitais: “(...) as camponesas a receberam com agrado e repartiam com ela do pouco que tinham para se manterem.” (AD, p. 90).; “(...) vejo que as moças ou conversam demasiadamente, ou em vendo gente, fogem, como se fossem animais de outra espécie, sem que haja quem lhes diga que o fugir é incivil grosseria, ou é tentar a curiosidade" (AD, p. 97);

3) Sentimento de impotência face o mundo natural: "Quem poderá mais crer nos enredos do Mundo, que apenas acaba um susto, já vai dispondo outros maiores?” (AD, p.174); "O quanto se ultraja a inocência, que deixa padrões para o escarmento! Ah cegos ministros da maldade, que lhes não lembra que serão severamente julgados pelos que 
puniram, sem mais culpa, que as que lhes imputaram a inveja, avareza e ódios!” (AD, p.175).

Até o século XVII, os fenômenos sobrenaturais eram aceitos como estranhos, mas receptíveis; vem depois a consciência da impotência humana diante da insegurança a que estão sujeitas as sociedades, quer urbanas, quer rurais.

Incapaz de, em sua solidão, dar conta do mundo, Theresa Margarida se volta ora para o Deus criador judaico-cristão: "Mas se estes pesares qualificam o meu sofrimento, triunfe a Constância, pois a resignação é princípio de felicidade.” (AD, p.27), ora para os deuses pagãos mitológicos que povoam o cenário grego de sua história: “(...) e então mais vivamente voltando para os benignos deuses, lhes dizia: Antes me entregai ao poder das Fúrias, que naufraguem no turbo Letes os avisos de meus bons progenitores.” (AD, p.19).

Reforce-se a ideia de que, entre os séculos XVI e XVIII, estabelece-se um forte debate entre homem e mulher, com base, principalmente, no setor econômico. O mundo moderno estava se formando economicamente; os Estados se compunham com base no mercantilismo que, de certa maneira, rasgava o pano de fundo constituído pelo espírito intocável e arrogante da Igreja.

O aparecimento de novas crenças religiosas destrói a hegemonia da Igreja Católica e procura derrubar um conjunto de imagens ligadas à santidade e à pureza femininas. Essas imagens foram criadas pela própria Igreja, no momento em que as ideias de malignidade e de feitiçaria atribuídas às mulheres não eram mais que um escudo de defesa para um autoritarismo masculino em vias de ser destruído.

Em Theresa Margarida, o sentimento religioso demonstrado, marca de desespero ou crença real, fornece um quadro marcado pela predominância da ordem divina, que caracteriza sua escrita. São os céus que determinam sua visão de mundo, pelas estruturas mentais já condicionadas. Busca encontrar coerências (e/ou incoerências) nos temas invocados, como se procurasse uma ordem no universo:

1) Os relatos sociais mostram os grupos dominantes, sublinhando o lugar do homem e da mulher na criação, no que não difere nem se afasta da visão de Milton e seu paraíso masculino;

2) O conhecimento do passado e do presente, e sua valoração.

Como porta-voz do grupo social a que pertence, o todo, para Theresa Margarida, é um conjunto de quadros mentais, colocando lado a lado a visão do pequeno grupo familiar 
e a visão social. Como exemplo, na figura de sua personagem Hemirena, a função de filhamulher, na voz do Pai, é submissa e controlada:

Amada filha,... conserva sem desmaios as sólidas doutrinas da tua educação, o exercício das virtudes, e a lembrança da distinção com que nasceste, para serem sempre nobres as tuas ações: teme os Deuses, ama constante o decoro, despreza o ócio e segue o teu destino - ao que Hemirena só respondia com o pranto. (AD, p.11).

Poder-se-ia dizer que a autora critica e se mostra contra essa autoridade constituída? $\mathrm{Ou}$ simplesmente a escritora ilustra seu texto com fenômenos que, embora rápidos, persistiram por séculos, marcando sua identidade feminina e portuguesa, como os fados, os destinos, a presença das Parcas?

E quais as marcas dos grupos sociais em que está inserida? Ainda à luz de Mandrou, encontrar as coerências e as incoerências dos temas invocados pela autora é colocar em forma a noção de visão de mundo.

Para os homens do século XVI, os fatos marcantes do século XV, como as descobertas das Índias, as viagens de Vasco da Gama, as revelações de Copérnico e Galileu a respeito do planeta conhecido foram renovações, ou antes, revoluções do mundo histórico e geográfico.

Além dessas renovações, os relatos sociais, o lugar do homem na criação, o conhecimento do passado e do presente, a possível ideia de futuro, tudo constituía o conjunto dos quadros mentais, intelectuais e étnicos dos indivíduos e dos grupos, a cada dia, desenvolvendo seu pensamento e sua ação (MANDROU, 1979 P.347).

Esse conhecimento permitirá conhecer uma tipologia de reconstrução de visões socializadas, sendo o grupo o que importa, ele é quem sente o peso dos conformismos sociais, que massacra os individuais. Fruto dos tempos e das mentalidades, o século XVIII desenvolverá ideias e filosofias em que a busca do individual tende para o encontro do sujeito que parecia perdido.

Consideradas a organização do macrocosmo que é o Estado - que ela critica e abomina na forma como está representado - e a do microcosmo que é sua família - que ela gostaria de ver perfeita -, questiona-se: como Theresa Margarida explora essa viagem para dentro de si mesma, na busca do individual que se realize como sujeito? 
"Como escritora, vemos que Theresa Margarida conduz suas personagens a submeterem-se às leis e ao poder dos superiores" (COELHO, 1995 P.28), sempre reforçando a ideia de fazê-lo não docilmente, mas com dor e sofrimento.

Ora, falar da realidade não fazia parte da natureza feminina do século XVIII, já que a mulher estava circunscrita a duas forças:

- A força do bem - quando maternal e delicada, dedicada ao lar, aos filhos, à obediência.

- A força do mal - quando usurpadora das atividades masculinas, ameaçadora e independente.

$\grave{A}$ frente de seu tempo, Theresa Margarida permite-se expressar suas ideias na exploração da palavra, fazendo uso de metáforas, de alegorias e de mitos que, de uma certa forma são transgressões para que se torne sujeito de sua história. Tal qual Hemirena, que se traveste de homem porque lhe são negadas autonomia e subjetividade, necessárias à criação de seu próprio universo plenificado com suas próprias escolhas.

A autora lusa transgride com um discurso agressivo, dominante, que transforma sua ausência desejada por uma presença que busca soluções por si, mesmo que precise adotar atitudes "masculinizadas". No entanto, esse discurso não dá conta da realidade de sua presença ou de sua existência.

Assim sendo, explora um universo ficcional sabido, quer pelo mundo conhecido, quer pelo desconhecido, onde se destacam as viagens, os labirintos, as cavernas.

As viagens, por exemplo, reais ou imaginárias, "atestam interesse universal por tudo aquilo que se refere ao reconhecimento da multiplicidade das formas concretas de existência das sociedades humanas, no tempo e no espaço" (FALCON, 1993, p.109). Falar em uma mentalidade ilustrada é restringir a experiência cosmopolita do século XVIII a uma parcela mínima, própria dos que sabiam ler.

Os centros de irradiação do movimento ilustrado são a França, a Inglaterra, a Itália e a Alemanha; por outro lado, os países receptores apresentam sociedades defasadas, que buscam uma ideologia de progresso: Espanha, Portugal, Suécia, Rússia, Polônia e parte do Império Otomano. Como traços de união: intelectuais ilustrados viajando, encontrando-se em salões socioculturais, integrando sociedades literárias, lojas maçônicas (Alemanha), universidades (Itália) etc.

Tomando-se como exemplo o terremoto de Lisboa, 


\section{Disiamentery}

DESASSOSSEGO 17 | JUN/2017 | ISSN 2175-3180

DOI: http://dx.doi.org/10.11606/issn.2175-3180.v9i17p85-101

o incidente deu origem a uma vasta literatura e às mais diversas interpretações. Para uns, o castigo divino fulminou os pecados dos homens e o seu orgulho; para outros, foi a demonstração da fragilidade da existência humana; para muitos, a negação plena do otimismo, típico do século das Luzes. (FALCON, 1993, p.105)

$\mathrm{Na}$ sociedade europeia em busca de si mesma, a literatura acompanha os fatos. Surgem, especialmente na Inglaterra, "as novelas ou relatos de aventuras", tendo como características o fato de serem histórias longas e movimentadas, cheias de imprevistos, onde não há fronteiras. A precariedade nos transportes e os recursos escassos levam a acidentes, quarentenas e, acima de tudo, naufrágios.

Em todos os tipos, a viagem é uma estratégia para se atingir a alteridade. Como exemplos, temos o tipo didático, em Robinson Crusoe, de Daniel Defoe; o tipo satírico, em Viagens de Gulliver, de Jonathan Swift; o tipo humorístico, em Tom Jones, de Henry Fielding.

Tendo Theresa Margarida cruzado o Atlântico bem cedo, na tenra idade, é difícil se afirmar sob que fantasia criadora ou "mentira literária" vai se desenvolver seu relato como narradora de viagens em Aventuras de Diófanes. Ela não é um narrador-personagem que participe da viagem pelas ilhas gregas, mas um narrador ausente que - concomitantemente - analisa o interior de seus personagens, enquanto observa os acontecimentos exteriores, (GENETTE, 1972) presente, assim, pelo conhecimento e pela onipotência.

Em Theresa Margarida, o que se nota é que As Aventuras de Diófanes e as aventuras de Hemirena não se relacionam nem com uma narrativa de viagens nem com uma viagem imaginária.

Sua aventura não se mostra como uma sucessão linear de descrições de locais visitados ou de experiências, nem se mostra como uma tentativa de apropriação de ideias, mas como uma viagem imaginária que serve de cenário para uma ideologia: a angústia da [re]união da família. Cada parada, cada saída ou entrada em uma ilha ou palácio, cada despedida e cada retorno é uma aventura maior, em que a heroína supera uma dificuldade, confronta-se com o meio adverso e supera o Outro (o estrangeiro) na construção de sua própria heroicidade, tecendo a grande aventura de ser mulher.

No vai-e-vem da Princesa Hemirena, Theresa Margarida evoca as leituras (que com certeza ela fez), apresentando descrições semelhantes das tempestades, grande personagem dessas histórias, como em Gulliver (SWIFT, 1931, p.19) ou em Robinson Crusoe (DEFOE, 1975, p.36). Viajar, velejar, conquistar, descobrir, naufragar são ações inscritas na 


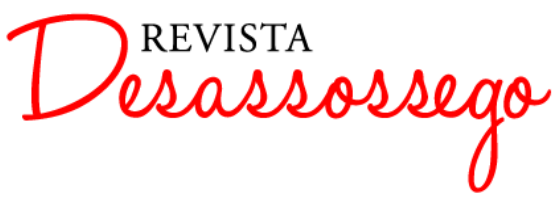

DESASSOSSEGO 17 | JUN/2017 | ISSN 2175-3180

DOI: http://dx.doi.org/10.11606/issn.2175-3180.v9i17p85-101

identidade portuguesa, desde o século XV, com D. Manuel, e que alcançam o século XVIII.

Para a escritora portuguesa, a escolha do tema está presa a essa marca identificatória lusitana, muito mais que uma escritura de época, marcada pelas influências inglesas. Naufragar é o "fazer modificador" que caracteriza, na narração, as mudanças, as angústias, a ansiedade do retorno e da salvação. Salvar-se é um estado mental em que a autora busca a [re]construção de si mesma na personagem Hemirena, resgatando da memória coletiva sua marca individual.

Seria ousadia colocar Theresa Margarida como precursora de uma característica romântica, a figura dos labirintos percorridos, pelas idas e vindas entre as ilhas do Mar Egeu; fosse buscando o Amor ou a saída do problema (para Hemirena), fosse sugerindo uma posição feminina de dúvidas e confusão, mas também de busca de respostas, em que a figura se torna mítica?

As passagens mais fortes são vistas como abordagens labirínticas do mistério de vida e do mundo. No centro de cada aventura, uma dificuldade maior se avoluma e faz a heroína recomeçar tudo por outro ângulo.

No intuito de ser melhor entendida essa imagem do labirinto barroco, é pertinente um olhar para as análises feitas por Ana Hatherly (1983) que, se por um lado não discute as várias correntes artísticas dos séculos XVII e XVIII, por outro lado auxilia o leitor a identificar as correntes predominantes daquela época com o olhar contemporâneo.

Tendo em vista a visão anagramática da autoria, manifestada na edição de 1750 das Aventuras de Diófanes, diz Hatherly que a origem dos anagramas remonta à cabala hebraica, desenvolvida a partir de um momento aproximado do hermetismo greco-romano, teoria em que a analista portuguesa se aprofunda em seus estudos.

Segundo Hatherly, alguns historiadores modernos consideram que os conceitos de hermetismo e até magia estão ligados não só à história das religiões como ao início do pensamento científico, no momento experimental.

Hermes (=Thot) era quem media o tempo e determinava a duração da existência, dele dependendo a vida ou a morte. Também a ele eram atribuídas as invenções da escrita e das ciências que dela dependem e, como consequência, a magia. Medicina, astrologia, alquimia, leis da criação estão sempre sob fórmulas mágicas.

Nos estudos de Theresa Margarida, conforme dito pela voz de Hemirena à princesa Beraniza, estavam incluídos Poesia, Artes, Astronomia, próprios para o público feminino, 
que também fora, em tempos anteriores não muito distantes, acusado de magia e feitiçaria por esses conhecimentos.

Também à escolha dos nomes dos personagens de Theresa Margarida podem ser atribuídos sentidos, como (1) $\underline{\text { Hermes }}$ (= mensageiro, intérprete da vontade dos deuses) / corresponde a Hemirena; (2) Beraniza / Berashit (= primeira palavra do Gênesis, em hebraico) / aludindo a Berenice (= a rainha do Egito, que prometeu seus longos cabelos a Afrodite, se seu marido, Ptolomeu III Evérgeta retornasse são e salvo da guerra contra os assírios).

Do cabalismo entendem-se duas doutrinas: a esotérica, que diz respeito à maneira de ler e escrever a lei (Torah) e ao sentido místico dos caracteres sagrados; a exotérica, dividida em teoria e prática, onde impera o gosto pelas charadas e adivinhas. Em Theresa Margarida, as perguntas feitas para Climenéia (Delmetra), no casamento dos pastores, têm um leve ar de charadas, não pela forma cabalística do significado das letras, números e palavras, mas pelo sentido dado às questões.

Essa leitura permitida pelo texto não coloca a romancista portuguesa ligada às ciências ocultas mencionadas, mas mostra a importância do pensamento emblemático e alegórico que está na base do pensamento barroco por onde passa o protorromance em questão.

Sendo a Renascença uma época emblemática por natureza, o Barroco é seu mais fiel herdeiro, principalmente analisadas as relações entre "palavra" e "imagem", entre "representação" e "figuração". Theresa Margarida permite ideias visíveis através das imagens sugeridas na escrita. O labirinto literário apresenta percursos simbólicos. Por exemplo, o labirinto formal da frase, de que Hatherly não dá conta, pode representar a odisseia humana em uma viagem labiríntica na luta pela afirmação da vida e, em especial, do gênero, como identificador sexual.

As frases centopeicas ou labirínticas se combinam e, progressivamente, deixam entrever o labirinto espiritual da personagem e da autora, levando ao palimpsesto ou possibilidade de um texto esconder o outro, sempre repensando a própria aventura humana de ser mulher.

Em Theresa Margarida, o labirinto tem o sentido de sua própria existência.

Percorre um labirinto de idas e vindas, entre ideias, ideais e vivências, na busca incessante de soluções, encontros e acertos que marcaram sua vida. $\mathrm{Na}$ juventude, entre o amor proibido pela lei paterna e permitido pela Lei do Estado; a atitude desconcertante do 
pai que a acusa em testamento e a deserda; no casamento, entre a realização e as dificuldades financeiras; na obra publicada após a morte do pai, sem que este tivesse a possibilidade de compreendê-la e perdoá-la; na maturidade, vivenciando três reinados diferentes em Portugal, vista como assessora e como intrigante e presa sem sursis; na velhice sem apoio ou proteção, apesar dos 14 filhos que a história lhe atribui.

Nesse jogo de reflexos entre realidade e ilusão podemos encontrar, também, semelhanças com o mito da Caverna, de Platão.

Na construção da personagem Delmetra, percebe-se a presença da caverna em seus dois significados, o positivo e o negativo. Céu e inferno estão unidos no simbolismo da reconciliação desses potenciais negativos e positivos. Diz Delmetra, quando Hemirena, travestida em Belino, a encontra escondida (ou abrigada?) em uma brenha de um rochedo:

(...) quando ouviu uma voz que dizia: Quem és, o que duvidas entrar no frio centro deste rochedo, que eu habito? Não temas, nem fujas: se és racional, chega a consolar a quem nesta sepultura paga tributo à desgraça. Não seja maior em ti o efeito da covardia que o da compaixão, que merece uma infeliz. (AD, p.52) [grifo nosso].

A construção do mito, na sociedade patriarcal, determina as diferenças de significados: 1) a mulher restrita ao ambiente doméstico, como prisão e imposição social, que reverte em prazer essa obrigação de limpar, lavar, cozinhar, parir, criar, pelo trabalho simbólico da tecelagem, do entreligar os fios familiares, responsável pelo sucesso e bem estar do clã; 2) a mulher poderosa que distingue, pela analogia de formato, seu corpo com um centro uterino, que lhe dá um lugar nessa mesma sociedade, pelo mistério da vida e da transformação.

Afastada da pompa em que vivia e do respeito que lhe era devido, como rainha de Tebas, Delmetra viu-se jogada em um “abismo de misérias", mas defendeu-se: "Separei-me das gentes e busquei entre as feras o amparo, que me negavam os racionais; e debaixo destes penedos tenho procurado com lágrimas contínuas abrandar a ira dos Céus." (AD, p.53).

Há, na escritura de Theresa Margarida, um entrelaçar de misticismo e religiosidade, onde se confundem, além da Mitologia Grega, o Cristianismo e o Judaísmo, nas imagens sugeridas e nos vários significados e metáforas.

O livro de Daniel, por exemplo, sempre despertou interesse nos leitores da Bíblia. Narra experiências de jovens judeus, que fazem parte dos cativos da Babilônia, sob o 


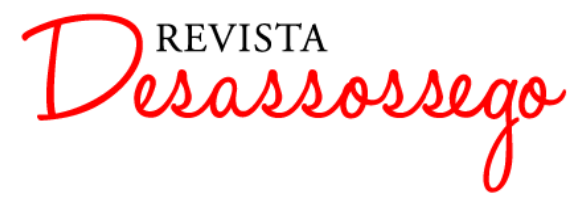

DESASSOSSEGO 17 | JUN/2017 | ISSN 2175-3180

DOI: http://dx.doi.org/10.11606/issn.2175-3180.v9i17p85-101

domínio de Nabucodonosor. Por fé e amor para com Deus, milagrosamente Daniel se viu livre da Cova dos Leões.

Escondida na caverna, como Daniel, Delmetra descreve sua vida:

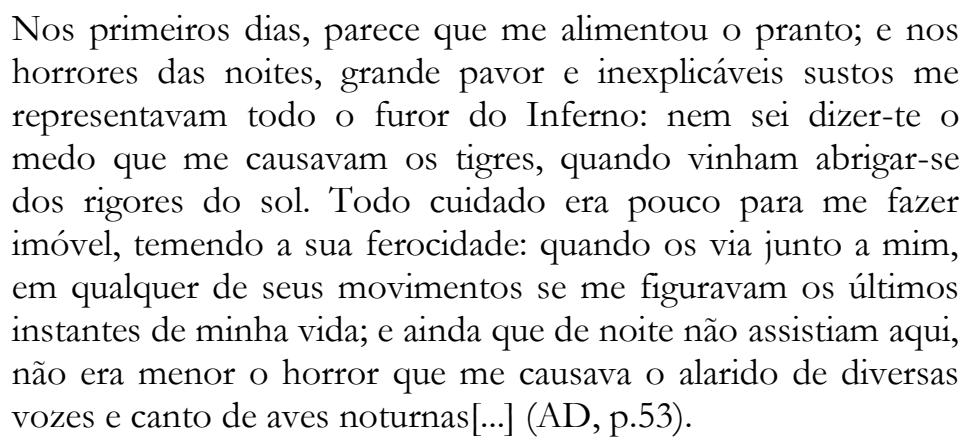

Simone de Beauvoir, uma das precursoras do feminismo do século XX, em $O$ Segundo Sexo (apud GILBERT e GUBAR, 2000. P.94), faz uma alusão à caverna de Platão, na descrição de uma cena na Tunísia, passada em uma caverna, onde mulheres exercem suas tarefas domésticas. Contrastam com a figura de um homem, em trajes claros, desprovido de cuidados e bem arrumado fisicamente, que entra sorridente, vindo do contato com o mundo exterior, livre de fumaças e cheiros do interior a que se submetem essas mulheres enclausuradas.

Nesse tecido intertextual, nota-se o herói perdido, como se houvesse voltado às sombras maternais - caverna, abismo, inferno. Para Hemirena/Belino, travestido e camuflado, o encontro com a mãe é uma forma de salvação, de reencontro de si mesmo, de consciência de sua sexualidade reprimida pelo disfarce.

Deméter, a quem, por analogia de nomes está representada em Delmetra (a mãe de Hemirena, Climenéia) é o arquétipo da Mãe, na mitologia Grega. Seu amor à filha, Perséfone, é único e exemplar.

Delmetra (mulher e mãe), escondida na caverna só pode ser salva e de lá retirada por um homem. É Belino (Hemirena travestida) que terá essa incumbência dada por Theresa Margarida.

Diz Delmetra:

Em acompanhar-te buscarei o meu remédio, pois tu me hás renovado o mal, com que já não pode o ânimo enfraquecido; mas vou certa que pelos Deus imortais juras acompanhar-me, como eu também a ti[...] (AD, p.58)

Paralelamente a estes pontos analisados, podem-se apresentar alguns mitos ocultos detectados nas relações entre a realidade literária e a realidade a que a literatura se refere. 
Interessa neste momento a leitura do recorte linguístico comparado ao recorte de outro sistema de signos: o Imaginário.

Como Theresa Margarida concilia o potencial metafórico das imagens para construir os mitos ocultos no seu texto?

Ao trabalhar com o Imaginário, latente e patente são constantes estudadas por Gilbert Durand, que permitem a [re]criação do texto literário pela repetição do relato. Durand vê, na psique profunda, acordos entre as características do indivíduo e as estruturas sociais. Segundo o antropólogo, as figuras que constituem o imagético humano são uma projeção do trajeto que o homem percorre, unindo seus imperativos biológicos (=gestos), psíquicos (=intenções) e pulsionais (=desejos) às intimações do meio social. (DURAND, 1997)

Embora de cunho social, a palavra escrita ou falada permite a criação de lacunas, posto que a textualização linear das referências se choca com a falta vocabular; a comunicação global é considerada o ponto chave da Pós-Modernidade: do velho se cria o novo, associando-se o signo alegórico da palavra usada pelo autor da obra (patente) ao imaginário do leitor (latente).

Assim sendo, a organização das imagens, feita por Theresa Margarida, pode levar o leitor a atrair novas imagens que, interagindo, criarão algumas estruturas simbólicas. Estas estruturas procuram decifrar a existência - sob o ponto de vista da historicidade - da escritora portuguesa, no tempo e no espaço, permitindo o entendimento não só da coerência do texto lido, mas a do mundo, pela análise compreensiva e pelo poder de interpretabilidade.

A exploração dos mitemas - navegação, nave, tempestade, ilha - mostram ao leitor atento sinais do universo mítico da autora.

O desvio do olhar de Theresa Margarida da sociedade portuguesa para outra sociedade ideal faz parte de seu universo mítico, que valoriza lugares, pessoas, ideias. É a busca de um cosmos harmonioso que destoa de seu mundo real. Faz parte de uma paisagem mental, idealizada, do mundo que ela quer substituir, retirando-lhe o papel negativo e caótico a que está determinado:

Soavam os instrumentos no mar ao compasso, em que as vozes repetiam em terra os vivas daqueles Soberanos, que em grande extremo eram amados dos vassalos, porque em seus domínios davam leis a justiça e a clemência, e o seu exemplo a melhor direção para os costumes... (AD, p.8). 
Por outro lado, a identificação do cenário de Theresa Margarida com o da Odisseia (ou mundo homérico) como que sobrepõe a imagem do cenário idealizado, perfeito, cristalizado e remete a um dos elementos principais do mito: as consequências de uma história que se narra, evidenciando-se a superioridade da cultura do Outro em outro tempo.

À luz da análise do imaginário de Durand, a escritora lusa cria uma teia textual, unindo seus gestos, suas intenções e seus desejos às intimações do meio social. A valorização da liberdade não é privilégio nem de homens nem de mulheres. Porém a liberdade de expressão é uma meta ambicionada principalmente pela escritora, representante de um segmento social emudecido pelas circunstâncias culturais.

Considerado o tripé autor-leitor-obra, o estudo da simbologia oferece a busca da equilibração entre os desejos ou aspirações desses três elementos - e as imposições do meio social e ambiente.

Por outro lado, a descoberta dos mitos ocultos no texto também pode auxiliar a desvendar o mistério da intenção comunicativa de sua história.

Ao se propor escrever Aventuras de Dioffanes, Theresa se mostra corajosa de enfrentar uma cultura onde as definições de autoridade literária são patriarcais. Isso não a assusta. Usará sua escrita para demonstrar não apenas uma façanha de autoria, mas como cenário para tradições de gênero, de estilo, de metáforas, como também "para os ecos, as alusões, as tentativas, os fantasmas de textos anteriores”, diz Miller (1977).

"Não tenho a pena de Homero", diz ela, mas mesmo assim, escreve, para que se entenda e se faça entender.

Falar e ser ouvida, essa a questão.

\section{REFERÊNCIAS BIBLIOGRÁFICAS}

COELHO, Nelly Novaes. A imagem da mulher do século XVIII: Aventuras de Diófanes, de Teresa Margarida. In Revista da Biblioteca Mário de Andrade. São Paulo: Secretaria Municipal de Cultura. 1995.

DAL FARRA, Maria Lúcia. Poesia de mulher em língua portuguesa. In Abrindo Caminhos homenagem a Maria Aparecida Santilli. Col. Via Atlântica n2 - São Paulo: Dep Pós ECLLP Lato Senso Edit, 2002)

DEFOE, Daniel. Robinson Crusoe. Trad. Elza Andringa. Coleção Europa-América. MiraSintra: Gráfica Europam Ltda, 1975. 


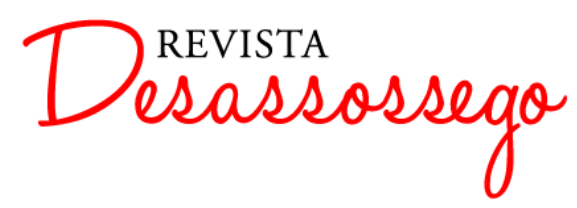

DESASSOSSEGO 17 | JUN/2017 | ISSN 2175-3180

DOI: http://dx.doi.org/10.11606/issn.2175-3180.v9i17p85-101

DURAND, Gilbert. Estruturas antropológicas do imaginário. Trad. Helder Godinho. São Paulo: Martins Fontes, 1997.

ENNES, Eduardo. Theresa Margarida da Silva e Orta - primeira escritora paulista e primeira romancista brasileira. Publicado pelo Instituto histórico-geográfico de São Paulo, separata do vol XXXV da Revista, impresso na Gráfica Paulista - no 8 - de 31p.

FALCON, Francisco José Calazans. A época pombalina - São Paulo: Ed. Ática, 1982

FOUCAULT, Michel. 1963 - Prefácio à Transgressão. In Estética: Literatura e Pintura, Música e Cinema. Coleção Ditos \& Escritos III. Org. Manoel Barros da Motta. Trad. Inês Autran Dourado Barbosa. Rio de Janeiro: Forense Universitária, 2009

GENETTE, Gerard. Figures III. Paris: Éditions Du Seuil, 1972.

GILBERT, Sandra M. \& GUBAR, Susan. The Madwoman in the Attic. Second Edition. New Haven: Yale University Press, 2000.

HATHERLY, Ana. A experiência do prodígio. Bases teóricas e antologia de textos-visuais portugueses dos séculos XVII e XVIII. Lisboa: Imprensa Nacional, Casa da Moeda, 1983

KADOTA, Neiva Pitta. A escritura inquieta. - Linguagem, Criação e Intertextualidade. São Paulo: Estação Liberdade, 1999

MANDROU, Robert. Magistrados e feiticeiros na França do século XVII. Uma análise psicológica bistórica. Trad. Jaime Guinsburg e Nicolau Sevcenko. São Paulo: Ed. Perspectiva, 1979

MILLER, J. Hills. The limits of pluralism III: the critic as host. Spring 1977, Critical Inquiry. Apud Madwoman in the Attic.

ORTA, Theresa Margarida da Silva e. Aventuras de Diófanes. Ministério de Educação e Saúde - Instituto Nacional do Livro - Biblioteca Popular Brasileira, nXVII - Prefácio e estudo bibliográfico de Rui Bloem - Rio de Janeiro: Imprensa Nacional, 1945

PÊCHEUX, Michel. Semântica e Discurso: uma crítica à afirmação do óbvio. Trad. Eni Pulcinelli Orlandi. Campinas, SP: Editora da UNICAMP, 1997.

REIS, Carlos. Técnicas de análise textual. Coimbra: Livraria Almedina, 1981.

SWIFT, Jonathan. Gulliver's Travels. New York: The modern Library, 1931. 